Судук О. Ю. [1; ORCID ID: 0000-0002-4620-4389],

К.С.-Г.н., доцент,

Щербакова А. C. [1; ORCID ID: 0000-0003-0972-821X],

к.е.н., доцент

${ }^{1}$ Національний університет водного господарства та природокористування, м. Рівне

\title{
КРЕАТИВНІСТЬ ЯК ОСНОВА РОЗВИТКУ ІННОВАЦІЙ ТА ЗАПОРУКА УСПІХУ ПРИ СТВОРЕННІ ТА РЕАЛІЗАЦІЇ СТАРТАП-ПРОЕКТІВ
}

У статті досліджуються поняття креативності та творчості; з'ясовується принципова відмінність креативності від суто творчої діяльності; визначені особливості процесу творчості і процесу креативності та структури творчості і структури креативності. Стаття присвячена питанням активізації сучасної підприємницької діяльності $з$ використанням творчого підходу для задоволення потреб i бажань споживачів та отримання оптимального прибутку в бізнесі за допомогою розвитку креативних привабливих ідей у взаємозв'язку таких понять, як «стартап», «інновація», «творчість». Приділено увагу інтрапренерству із застосуванням ініціативності та активності працівників. Запропоновано пріоритетні напрямки креативного підприємництва та розглянуто основні особливості реалізації стартап-проєктів в Україні.

Ключові слова: креативність; управління інноваціями; інвестиції; бізнес-планування; творче мислення; стартап-проєкт; проєктний аналіз; творчість; креативне підприємництво; конкурентоспроможність.

Постановка проблеми. Підприємництво і творчість формують основу розвитку бізнесу, оскільки глибоко перетинаються в межах будь-якої господарської діяльності. У підвищенні ефективності бізнесу важлива роль належить інтрапренерству (внутрішньому підприємництву), що базується на креативності та ініціативності фахівців компанії. У даній статті розглянуто необхідність формування креативних думок у бізнес-просторі для оптимального розвитку управлінської та корпоративної культури. Також розглянуто процес генерації творчих ідей та інноваційні засади щодо можливості створення, функціонування стартап-проєктів, розвитку креативного підприємництва.

Аналіз останніх досліджень і публікацій. 3 середини XX століття перш за все, іноземними науковцями почали проводитися дослідження креативності як основи інноваційності. Зокрема, найбільш відомими дослідниками креативності як інноваційного 
ресурсу були науковці: Е. Бустаманте, П. Бурдье, Д. Ренцуллі, Р. ДіазБоун, М. Хоркхаймер Р. Сімпсон, Дж. О'Коннор, С. Тейлор, М. Меттьюс, В. Франк, Т. Адорно, Д. Гілфорд, Дж. Мокир, Е. Торренс, Й. Клоудова, Б. Саліхов та ін. Теорія креативної економіки вивчалася у працях Дж. Хоккінс, Ч.Лендрі, Р.Флоріда. В Україні дослідженнями особливостей застосування інновацій та креативних процесів в економіці займаються такі вчені, як Б.Данилишин, О. Амоша. О. Біловодська, А. Чухно, С. Прилипко, Л. Федулова, Н. Краус, В. Геєць С. Давимука, А. Пакуліна, А. Мержвинська, Е. Лібанова, Т. Галахова, Ю. Сотнікова, І. Олександренко, І. Вахович, О. Дорошенко, С. Онишко, 0. Чуль та ін.

Виклад основного матеріалу дослідження. В умовах ринкової економіки конкуруючі самостійні фірми зацікавлені в наявності ринку нововведень, основу яких складають креативні ідеї та рішення. Відзначимо, що інновації $\epsilon$ досягненнями людського розуму, які призначені для підвищення ефективності всіх бізнеспроцесів в будь-якій сфері діяльності.

Нині визначальне значення науки та інноваційного бізнесу дозволяє ідеям перетворюватися в конкурентні досягнення. Але сьогодні навіть придбання передової технології не є гарантованою умовою створення конкурентної переваги. Отримають вигоду лише ті підприємства, які швидко розпізнають конкурентні можливості нової технології, ефективно комбінуючи свої матеріальні і нематеріальні активи.

М.Лапін зазначає, що для успішного використання нематеріальних активів важливо розрізняти явні (формальні) і неявні (неформальні) знання. Формальні знання - це доповіді, звіти та інші документи, які становлять близько $20 \%$ знань організації. Інша частина (майже 80\%) - це те, що неможливо формалізувати. Цими знаннями є інтуїція, досвід, навички, взаємовідносини, тобто те, що здобувається на практиці або частково передається від однієї особи до іншої. Практичної цінності знання набувають за умови існування сфери їх застосування. Знання реалізуються через креативну діяльність, що в кінцевому підсумку забезпечить доступ до нових ринків і створить бар'єри для входу конкурентів [1].

Основою інноваційної діяльності є творчість. Ось чому в цьому фундаментальному процесі важливими є дослідження особливостей креативності діяльності. Не рекомендується чітко розмежовувати поняття «творчість» i «креативність», тому що поняття «креативність» більшою мірою стосується сфери бізнесу. Крім того, креативність як творчість, здатність до дослідження орієнтована на практичний результат. 
Які ж переваги дає фахівцю розвинене творче мислення і безпосередньо пов'язана з ним винахідницька діяльність?

В свою чергу, творчість:

- змінює ставлення до життя, дає можливість самим стати тією силою, яка викликає зміни і формує майбутнє особистості;

- забезпечує швидкість думки і гнучкість мислення;

- сприяє розширенню знань, спектру застосовуваних методів, тому що при вирішенні різних проблем відсутній фокус лише на одному моменті і способі вирішення проблеми;

- скорочує часові і матеріальні витрати, необхідні для вирішення проблеми;

-збагачує внутрішній і зовнішній світ людини;

-наповнює життя радістю, сенсом, метою;

-підвищує впевненість у правильності обраних ідей;

- допомагає краще розуміти думки інших людей;

- допомагає відволіктися від стереотипів у мисленні;

- підвищує задоволення від вирішення проблеми, так зване «творче задоволення».

Креативність охоплює певну сукупність розумових і особистісних якостей, що сприяють творчому прояву. Нові ідеї і рішення виникають в результаті спільної участі логічного й інтуїтивного мислення людини, завдяки функціонуванню логіки та інтуїції в конкретних проблемних ситуаціях. Розвитку творчості сприяє сприйнятливий інтелект, збагачений різноманітним досвідом.

«Креативність можна прирівняти до інтелекту. Креативність включає здатність до синтезу. Вона формує не лише інтерес, а й впевненість в своїх силах. Людина повинна володіти здоровою самовпевненістю, щоб не боятися виступати з новаторськими ідеями і робити помилки, не звертаючи уваги на критику. Без сумнівів теж не можна обійтися, але вони не можуть завжди брати верх, незважаючи на скептицизм», - зауважує відомий американський дослідник феномена креативності Р. Флорида [2, С. 45-46].

Звідси можна зробити висновок, що показником високого рівня креативних здібностей є такі якості особистості, як нестандартність, почуття внутрішньої свободи, готовність до ризику, захопленість, самостійність і впевненість у собі. Іншими словами, креативність - 3 одного боку, $€$ творчим процесом, орієнтованим на пошук i формулювання нових ідей, а з іншого - це особистісна категорія, що відображає динаміку духовного розвитку особистості в умовах реалізації креативного процесу, орієнтованого на соціально значиму діяльність. У нових інноваційних умовах управлінської культури креативна діяльність стає не тільки практично доцільною, але багато 
в чому визначальною для конкурентоспроможності та прибутковості діяльності конкретних високотехнологічних підприємств і організацій.

Відповідно до словника Вебстера креативність як здатність створювати значущі нові форми, перетворилася на основне джерело конкурентної переваги. Практично в будь-якій сфері виробництва, від автомобілебудування до індустрії моди, харчової промисловості та інформаційних технологій, в кінцевому підсумку перемагає той, хто володіє творчим потенціалом. Це справедливо для будь-якої історичної епохи, починаючи 3 етапу сільськогосподарської революції і аж до промислової революції. Однак тільки в останні кілька десятиліть ми прийшли до ясного усвідомлення цього факту і почали діяти відповідно [2, С. 19-20].

Креативність сьогодні стає атрибутом самоактуалізації і самореалізації особистості. Креативні люди прагнуть до внутрішньої гармонії через реалізацію можливості проявляти свої здібності в будь-якій справі; творча робота сприймається ними як нагорода, спосіб самореалізації, є джерелом радості, визначає сенс життя. Розуміння екзистенціальної цінності актуального моменту дозволяє цінувати не тільки результат, але і сам процес діяльності. Креативні, орієнтовані на творчість люди здатні вносити в свою діяльність системні зміни, вони психологічно готові до інновацій у професійній діяльності. Таким чином, креативність, орієнтована на творчу, економічно і соціально прагматичну діяльність, генерування нових ідей, швидке вирішення проблемних ситуацій є однією з актуальних проблем у сучасному бізнесі. Дослідження в цій галузі, висновки і пропозиції життєво необхідні сучасним компаніям і в цілому державі, зацікавленій у пошуку інноваційного потенціалу свого розвитку.

Творче мислення дало поштовх для появи нової течії креативне підприємництво (creative entrepreneurship). У більш вузькому розумінні, креативне підприємництво відноситься до бізнесів, які працюють в рамках культурних і творчих індустрій. У різних країнах ці галузі мають різні визначення, але, в принципі, креативне підприємництво включає в себе сфери, які ґрунтуються на культурній творчості і капіталізують інтелектуальну власність. Сюди відносяться дизайн і мода, архітектура, аудіовізуальний сектор (промисловість, радіомовлення), видавнича справа, ЗМІ, візуальні мистецтва, музична індустрія, спадщина (музеї, бібліотеки, архіви), реклама і розваги (ігри, додатки). У більш широкому контексті креативне підприємництво також включає в себе перетин аспектів креативних галузей, що означає те, що культура і культурна творчість пов'язані з іншими напрямками і галузями виробництва, і вони є взаємовигідними [3].

Таким чином, до креативного підприємництва відносяться всі 
галузі діяльності і виробництва, які мають на увазі обов'язковий творчий підхід і пошук нових, нестандартних рішень.

Креативне підприємництво - це підприємництво в межах креативної економіки. Ключова особливість креативної економіки те, що вона заснована на знаннях, інформації та емоціях. Важливу роль у креативній економіці відіграє аналіз існуючих і відкриття нових знань, нові технології в різних сферах життєдіяльності [3].

В рамках креативної економіки створюються нові парадигми і моделі бізнесу. Також важливо відзначити, що на сьогоднішній день саме сектор креативної економіки створює найбільш високооплачувані робочі місця. Креативне підприємництво в корені відрізняється від звичних норм роботи, воно вимагає великих навичок, мобільності і здатності постійно вчитися. Без цього залишатися «на хвилі» просто не представляється можливим. Більшість креативних компаній - це маленькі або навіть мікропідприємства, дуже мобільні, часто сезонні, засновані на проєктах.

Креативне підприємництво має непогані позиції за кордоном. В ЄС культурні та творчі індустрії складають 4,4\% ВВП і налічують 7 млн співробітників. Креативні галузі $\epsilon$ не лише значними за розмірами, але і напрямками, що найбільш активно розвиваються. В Естонії, наприклад, 11,4\% всіх зареєстрованих підприємств працюють в творчих індустріях і складають 5\% зайнятості населення. 3 точки зору частки в ВВП, креативного підприємництва в Україні практично немає у порівнянні, наприклад, 3 6\% у Великобританії. Щоб зменшити відтік талановитих людей закордон необхідно розвивати сектори креативної економіки та підприємництва. Україна має сильний інтелектуальний потенціал, але з іншого боку, нам не вистачає трьох ключових складових - освіти, інфраструктури і інтеграції в західний світ. Проте, надія на розвиток креативного підприємництва в Україні $€$, з огляду на велику кількість стартапів і компаній, чиїм основним сервісом або продукцією можна назвати творчий підхід [3].

Щоб зберегти своє місце на ринку та бути конкурентоздатним в епоху новітніх технологій, потрібно рухатися в ногу 3 часом, використовуючи весь комплекс сучасних технологій та бізнесрішень. Таким чином, основним джерелом інноваційних ідей та нестандартних рішень для великого бізнесу стають стартап-проєкти.

Доказом розвитку ринку стартапів в світі та Україні, зокрема, є дослідження сервісу Startup Ranking, який проаналізував 136 країн світу, нарахував близько 100 тис. стартапів і визначив рейтинг країнлідерів за кількістю впроваджених стартапів. Перше місце, згідно зі Startup Ranking [4], належить США (47887 стартапів), а Україна 
посіла 43 місце (262 стартапи).

Станом на 2019 рік ринок українських стартапів знаходиться у стані активного розвитку. Згідно із дослідженням сервісу StartupBlink [5] - комерційного дослідного центру стартап-екосистем світу - Київ зайняв 34-е місце в рейтингу міст із найбільшою кількістю стартапів, які запускаються. У 2020 році Україна зайняла 29 місце в списку найбільш технологічних країн світу. При цьому Київ визнали європейським хабом. Столиця посіла вже 32 місце серед технологічних столиць світу. А в європейському рейтингу Київ посів 8 місце. Популярність України можна пояснити великою кількістю місцевих професіоналів, готових розвивати свій продукт. Вагомим фактором також стала низька вартість організації підприємництва саме це залучає західних інвесторів у країну.

Згідно з інтернет-ресурсом Marketer.ua [6; 7] існує 9 критеріїв успішності, серед яких: правильна мотивація, здатність до глобального мислення, легка та зрозуміла для користувачів ідея, готовність працювати над сумнівною ідеєю, креативність, працьовитість і наполегливість, віра у свою справу, наявність лідерських якостей у стартапера.

Наразі завдяки розвитку інформаційно-комунікаційних технологій стартапи знаходять все більше поширення у всьому світі як проєкти, які найбільш швидко реагують на сучасні проблеми населення, і завдяки яким покращується якість життя громадян. Вони $є$ потужним драйвером сталого економічного розвитку країни.

Висновки і перспективи подальших досліджень. Інновації у всіх областях життєдіяльності людини - найважливіша потреба теперішнього часу, яка полягає в перетворенні потенційного абстрактно-ідеального уявлення про науково-технічний прогрес в реальний, що втілюється в нових сенсах, цінностях, цілях, пріоритетах, продуктах і технологіях. При цьому інновації можна охарактеризувати як формування нового характеру мислення $\mathrm{i}$ ставлення до нього, новий напрямок діяльності, новий шлях і нову методологію (світогляд) формування та втілення рішень, а в підсумку - новий результат.

Щоб забезпечити розвиток ринку стартапів в Україні, необхідно створити та запровадити ефективні інструменти та механізми підвищення ефективності діяльності стартап-компаній. Водночас важливо створювати максимально комфортні умови для впровадження інноваційних технологій для успішного розвитку вітчизняних підприємств та економіки в цілому.

1. Лапин Н. М. Креативнось как инновационный ресурс развития экономики : дис. ... канд. эконом. наук. Тамбов, 2008. С. 38. 2. Флорида Р. Креативный класс: люди, которые меняют будущее. М. : Издат. дом «КлассикаXXI», 2017. С. 45-46. 
3. Креативное предпринимательство: как сделать творчество основой бизнеса? URL: https://ubr.ua/business-practice/own-business/kreativnoe-predprinimatelstvokak-sdelat-tvorchestvo-osnovoi-biznesa-342156 (дата звернення: 25.05.2021). 4. Startup Ranking. URL: https://www.startupranking.com/top/ukraine (дата звернення: 25.05.2021). 5. Global Map of Startup Ecosystems - StartupBlink. Haifa : Global Map of Startup Ecosystems. StartupBlink, 2020. URL: https://www.startupblink.com/ (дата звернення: 25.05.2021). 6. The Top 20 Reasons Startups Fail. CB INSIGHTS. URL: https://www.cbinsights.com/research/startupfailurereasons-top/ (дата звернення: 25.05.2021). 7. Відмінні ознаки успішного стартапу. Marketer. ua. URL: https://marketer.ua/ua/vidminni-oznakiuspishnogostartapu/ (дата звернення: 25.05.2021).

\section{REFERENCES:}

1. Lapin N. M. Kreativnos kak innovatsionnyiy resurs razvitiya ekonomiki : dis. ... kand. ekonom. nauk. Tambov, 2008. S. 38. 2. Florida R. Kreativnyiy klass: lyudi, kotoryie menyayut buduschee. M. : Izdat. dom «KlassikaXXI», 2017. S. 45-46. 3. Kreativnoe predprinimatelstvo: kak sdelat tvorchestvo osnovoy biznesa? URL: https://ubr.ua/business-practice/own-business/kreativnoe-predprinimatelstvo-kaksdelat-tvorchestvo-osnovoi-biznesa-342156 (data zvernennia: 25.05.2021). 4. Startup Ranking. URL: https://www.startupranking.com/top/ukraine (data zvernennia: 25.05.2021). 5. Global Map of Startup Ecosystems - StartupBlink. Haifa : Global Map of Startup Ecosystems. StartupBlink, 2020. URL: https://www.startupblink.com/ (data zvernennia: 25.05.2021). 6. The Top 20 Reasons Startups Fail. CB INSIGHTS. URL: https://www.cbinsights.com/research/startup-failurereasons-top/ (data zvernennia: 25.05.2021). 7. Vidminni oznaki uspishnogo startapu. Marketer. ua. URL: https://marketer.ua/ua/vidminni-oznakiuspishnogo-startapu/ (data zvernennia: 25.05.2021).

Suduk O. Yu. [1; ORCID ID: 0000-0002-4620-4389], Candidate of Agricultural Sciences (Ph.D.), Associate Professor, Shcherbakova A. S. [1; ORCID ID: 0000-0003-0972-821X], Candidate of Economics (Ph.D.), Associate Professor

${ }^{1}$ National University of Water and Environmental Engineering, Rivne

\section{CREATIVITY AS A BASIS FOR THE INNOVATION' DEVELOPMENT AND THE GUARANTEE OF SUCCESS IN CREATING AND IMPLEMENTING THE START-UP PROJECTS}

The article deals with the concept of creativity and creative activity, specifies the fundamental difference between creativity and creative activity, determines the features of the creative activity process and the creativity process, the creative activity structure etc. This article reveals the problems of modern entrepreneurial activity' activation with the use of creative approach for satisfaction of necessities and desires of buyers and receiving the optimum income in business by development of creative attractive ideas in intercommunication of such concepts as an enterprise, innovation, creation. 
Creativity encompasses a certain set of mental and personal qualities that contribute to creative expression. New ideas and solutions arise as a result of the joint participation of logical and intuitive human thinking, through the functioning the logic and intuition in specific problem situations. Creativity is promoted by the receptive intellect, enriched by various experiences.

Entrepreneurship and creativity form the basis of business development, as they intersect deeply within any economic activity. Intrapreneurship (internal entrepreneurship), which is based on the creativity and initiative of the company's specialists, plays an important role in improving the business efficiency. The need of forming the creative ideas in the business space for the optimal development of management and corporate culture has been grounded. The process of generating creative ideas and innovative principles on the possibility of creating, functioning the start-up projects, development of creative entrepreneurship have been considered.

Keywords: creativity; innovation management; investment; business planning; creative thinking; startup project; project analysis; creativity; creative entrepreneurship; competitiveness.

Судук Е. Ю. [1; ORCID ID: 0000-0002-4620-4389], К.С.-Х.Н., доцент, Щербакова A. C. [1; ORCID ID: 0000-0003-0972-821X], к.э.н., доцент

\title{
КРЕАТИВНОСТЬ КАК ОСНОВА РАЗВИТИЯ ИННОВАЦИЙ И ЗАЛОГ УСПЕХА ПРИ СОЗДАНИИ И РЕАЛИЗАЦИИ СТАРТАП-ПРОЕКТОВ
}

\begin{abstract}
В статье исследуются понятия креативности и творчества; определено принципиальное отличие креативности от творческой деятельности, особенности процесса творчества и процесса креативности, а также особенности структуры творчества и структуры креативности.
\end{abstract}

В статье рассмотрены проблемы активизации современной предпринимательской деятельности с использованием творческого подхода для удовлетворения потребностей и желаний покупателей и получения оптимальной прибыли в бизнесе с помощью развития креативных привлекательных идей во взаимосвязи таких понятий, как «предпринимательство», «инновация», «творчество». Уделено внимание интрапренерству с учетом инициативности и активности работников.

Ключевые слова: креативность; управление инновациями; инвестиции; бизнес-планирование; творческое мышление; стартап-проект; проектные анализ; творчество; креативное предпринимательство; конкурентоспособность. 